\title{
Retraction: Human gut microbiota: dysbiosis and manipulation
}

\section{Frontiers in Microbiology Editorial Office *}

*Correspondence: microbiology.editorial.office@frontiersin.org

\section{Approved by:}

Martin G. Klotz, University of North Carolina at Charlotte, USA

\section{A retraction of the Opinion Article:}

Human gut microbiota: dysbiosis and manipulation

by Shen, D., Liu, C., Xu, R., and Zhang, F. (2012). Front. Cell. Infect. Microbiol. 2:123. doi: 10.3389/fcimb.2012.00123

The authors and the journal wish to retract the 27 September 2012 article cited above. Based on information discovered after publication and reported to the journal in November 2013, this article was found to contain sections that were taken verbatim from other sources without giving proper reference to the source and without identifying the citation as a word-by-word citation from that source. The authors agree with retraction of the article and apologize to the readers, reviewers, and editors of Frontiers in Cellular and Infection Microbiology.

Received: 06 December 2013; accepted: 06 December 2013; published online: 19 December 2013.
Citation: Frontiers in Microbiology Editorial Office (2013) Retraction: Human gut microbiota: dysbiosis and manipulation. Front. Cell. Infect. Microbiol. 3:104. doi: 10.3389/fcimb.2013.00104

This article was submitted to the journal Frontiers in Cellular and Infection Microbiology.

Copyright (c) 2013 Frontiers in Microbiology Editorial Office. This is an open-access article distributed under the terms of the Creative Commons Attribution License (CC BY). The use, distribution or reproduction in other forums is permitted, provided the original author(s) or licensor are credited and that the original publication in this journal is cited, in accordance with accepted academic practice. No use, distribution or reproduction is permitted which does not comply with these terms. 